\title{
Using a Novel Nanoparticle as An Adjuvant for Inactivated Avian Influenza Vaccine
}

\author{
Amani Mohamed Abbas ${ }^{1}$, Abd El-Moneam ${ }^{1 *}$ M.M., H.M. El Naggar ${ }^{1}$, S.I. El-Dek ${ }^{2}$, A. A. \\ Farghali ${ }^{2}$, and Mohamed Fekry El Kersh ${ }^{3}$ \\ ${ }^{1}$ Veterinary Serum and Vaccine Research Institute, Abbasia, Agricultural Research Center, Cairo, Egypt. \\ ${ }^{2}$ Material Science and Nanotechnology Department, Faculty of Postgraduate studies for advanced sciences, \\ Beni- Suef, Egypt. \\ ${ }^{3}$ Animal Health Research Institute, Dokki, Agricultural Research Center, Giza, Egypt. \\ *Corresponding Author: Abd El-Moneam M.M., E-Mail: dr_mahmoud_vsvri@yahoo.com
}

\begin{abstract}
The present work evaluated the mesoporous silica nanoparticles (MSNs) as a promising adjuvant in preparation of inactivated avian influenza H9N2 vaccine in chicken. Two inactivated vaccine formulae were prepared by using Montanide ${ }^{\mathrm{TM}}$ ISA $71 \mathrm{VG}$ and MSNs as adjuvants. Both vaccine formulae were found to be sterile and safe from local or systemic post-vaccinal reactions. Regarding the vaccine potency, it was found that antibody titer against H9N2 strain was detected in chickens of the group (2) that received the inactivated H9N2 vaccine with MSNs adjuvant and the highest antibody titer $\left(9.6 \log _{2}\right)$ was detected early at both $2^{\text {nd }}$ and $3^{\text {rd }}$-week post-vaccination using haemagglutination inhibition test. On the other hand, the antibody titer against the H9N2 virus in chickens of group (1) vaccinated with the inactivated H9N2 vaccine adjuvanted with Montanide ISA 71 was $\left(5.3 \log _{2}\right.$ and $\left.8.6 \log _{2}\right)$ at $2^{\text {nd }}$ and $3^{\text {rd }}$-week post-vaccination respectively and reached its maximum value at $4^{\text {th }}$-week post-vaccination $\left(9.0 \log _{2}\right)$. The results of viral shedding in group (1) vaccinated by Montanide ISA 71 H9N2 vaccine showed only virus shedding of $9.3 \times 10^{2} \mathrm{EID}_{50}$ and $\mathrm{Ct}$ value of $35.532^{\text {nd }}$ day postchallenge (DPC) using Real-time RT-PCR. While in group (2) received MSNs and $\mathrm{H} 9 \mathrm{~N} 2$ vaccine detected no virus shedding at $2^{\text {nd }} \mathrm{DPC}$, later viral shedding was detected at a rate of $2.4 \times 10^{2}$ (Ct value of 24,24$)$ and $4.2 \times 10^{2}$ (Ct value of 26.77) at $4^{\text {th }}$ and $6^{\text {th }}$ DPC respectively in comparison with the control unvaccinated group (3) that had the highest virus shedding value ranged from $3.5 \times 10^{7}$ (Ct value of 20.34) at $2^{\text {nd }}$ DPC to $3.08 \times 10^{6}$ (Ct value of 23.92) at $6^{\text {th }}$ DPC. The present work proved the efficacy of silica nanoparticles as a possible adjuvant for inactivated Avian Influenza H9N2 vaccine.
\end{abstract}

Keywords: Adjuvant, AI-H9N2, Mesoporous Silica Nanoparticles, Montanide ${ }^{\mathrm{TM}}$ ISA $71 \mathrm{VG}$, (MSNs).

\section{Original Article:}

DOI:https://dx.doi.org/10.21608/javs.2 $\underline{021.100437 .1110}$

Received :11 October, 2021. Accepted :01 December, 2021. Published in January, 2022.

This is an open access article under the term of the Creative Commons Attribution 4.0 (CC-BY) International License. To view a copy of this license, visit:

http://creativecommons.org/licenses/by/4.0/

J. Appl. Vet. Sci., 7 (1 ): 31-37.

\section{INTRODUCTION}

In many countries, avian influenza (AI) H9N2 has become a major threat in the poultry sector. Despite the fact that H9N2 viruses are classified as low pathogenic avian influenza (LPAI), they constitute a considerable threat to public health as they have the potential to become pandemic (Syamsiah Aini et al., 2019).

In 1966, Avian Influenza H9N2 viruses were first isolated in turkeys. It then appeared in a variety of terrestrial, avian species and is now one of the most endemic subtypes in chickens (Naguib et al., 2019; Ali et al., 2018). The first isolation of $\mathrm{H} 9 \mathrm{~N} 2$ in Egypt was in 2011 where the virus was isolated from commercial bobwhite quail. The hemagglutinin gene sequence of the isolated Egyptian viruses showed the highest similarity with one of the recent Israeli strains (97\%) detected from 2006 to 2010 (El-Zoghby et al., 2012).

The successful vaccination process depends on improving two main components of vaccines: the biological component represented in the antigen and the appropriate adjuvant. As the adjuvant is critical for enhancing the proper immunogenicity of the biological component, the existence of an excellent adjuvant is required for the biological component as it cannot induce strong humoral and cellular immune responses alone (Delany et al., 2014). 
Dimension of Nanoparticles ranges from 1$100 \mathrm{~nm}$, especially in drug delivery. The drug may be in different forms as dissolved, entrapped, encapsulated or attached to a nanoparticle matrix (Swami et al., 2012). The hydrophilic surface of nanoparticles blocks opsonization and allows easier internalization, while the hydrophobic core is beneficial for drug loading. Silicon dioxide (Silica) nanoparticles are the most favorable nanoparticle adjuvant candidates. There are particles with a diameter of less than $100 \mathrm{~nm}$ and different structures such as mesoporous Silica (Mercuri et al., 2006).

Mesoporous silica materials were received considerable attention due to their superior textual properties such as large pore volume, tunable pore diameter, high surface area, and narrow pore size distribution (Kresge et al., 1992).

Because of their excellent chemical properties, thermal stability, and biocompatibility, mesoporous silica nanoparticles (MSNs) are frequently used as delivery agents. Their active surface allows functionalization to modify surface properties and link therapeutic molecules (Bharti et al., 2015). The mesoporous form of silica has unique properties, especially when therapeutic loading agents are in high quantities and subsequent releases. Because of the solid Si-O bond, Silica-based mesoporous nanoparticles are more stable to external responses such as degradation and mechanical stress than niosomes, liposomes, and dendrimers, which inhibit the need for any external stabilization in the synthesis of MSNs (Sooyeon et al., 2013).

Due to the harmful impact of avian influenza (H9N2) on poultry production, this work aims primarily to improve the adjuvant used to potentiate immune response. This will be done through the use of modern adjuvants such as MSNs and comparing it with the currently used adjuvant Montanide ${ }^{\mathrm{TM}}$ ISA 71 VG.

\section{MATERIALS AND METHODS \\ Ethical approval:}

The present work was approved by the Institutional Animal Ethics Committee of Veterinary Serum and Vaccine Research Institute. All procedures and chick's care were carried out in accordance with the institutional guidelines for animal use in research.

\section{1-The virus:}

Egyptian local isolate of influenza A virus strain A/chicken/Egypt/114922v/2011(H9N2) was kindly provided by National Laboratory for Veterinary Control on Poultry Production, Animal Health Research Institute (NLVCPP/AHI), Egypt. The sequence of this virus is registered in the Genebank under the accession number: AIV (JQ419502).

\section{2-Adjuvants:}

\section{1-Montanide ${ }^{\mathrm{TM}}$ ISA 71 VG:}

It is a mineral oil-based adjuvant manufactured and developed by SEPPIC Co. (France) for manufacturing water-in-oil (W/O) emulsion. It is routinely used for vaccine production at Veterinary Serum and Vaccine Research Institute. (VSVRI), Abbasia, Cairo.

2.2- Silica nanoparticles (mesoporous silica nanoparticles, (MSNPs) :

MSNPs were provided from Material Science and Nanotechnology Department, Faculty of Postgraduate Studies for Advanced Sciences, Beni- Sueif University.

Preparation of MSNPs: methods described by (AbouAitah et al., 2016)

One gram of cetylpyridinium bromide hydrate (CPB) and $0.6 \mathrm{~g}$ of urea were dissolved in $30 \mathrm{ml}$ of deionized water with continuous stirring for $30 \mathrm{~min}$. Cyclohexane $(30 \mathrm{ml})$ and isopropanol $(1.2 \mathrm{ml})$ were added to the solution. Under strong stirring at room temperature, Tetraethyl Orthosilicate (TEOS) $(2.7 \mathrm{ml})$ was gently added dropwise to the mixed solution in 5 min. After $30 \mathrm{~min}$ of sturdy stirring, the reaction mixture was heated to $85{ }^{\circ} \mathrm{C}$ and kept for 17 hours at $4^{\circ} \mathrm{C}$. The mixture was centrifuged and thoroughly washed with acetone and water several times. MSNs were left to dry for $12 \mathrm{hrs}$. at room temperature. To remove the template surfactant molecules from the mesoporous, the as-synthesized material was calcined at $600^{\circ} \mathrm{C}$ for six hours. The resulting material was characterized using Field emission scanning electron microscopy Quanta FEG (FESEM).

\section{3-Preparation of the aqueous phase (virus):3.1- Propagation and titration:}

Propagation and titration of H9N2 were done in specific pathogen-free eggs (SPF) 9 -10 day old embryonated chicken egg (ECE) according to methods described by OIE, (2019). Its titer was $10^{9} \mathrm{EID}_{50} / \mathrm{ml}$.

\section{2-Virus inactivation:}

According to (OIE, 2019), inactivation of AI virus was carried out using formalin in a final concentration of $0.1 \%$ of the total volume drop by drop during blending on a magnetic stirrer for $18-20 \mathrm{hrs}$. at $25^{\circ} \mathrm{C}$.

\section{3-Compeletion of inactivation:}

The final concentration of $2 \%$ sodium bisulfite solution was added as a residual formalin neutralizing agent. Two blind successive passages on ECE were carried out before the antigen was considered safe. 


\section{4-Scanning electron micrographs:}

It was carried out for monitoring and confirmed carrying efficacy of Nanoparticle and viral particles at Materials Science and Nanotechnology Department, Faculty of Postgraduate Studies for Advanced Sciences, Beni-Sueif University according to (Zongxi et al., 2012 and Liu et al., 2019) Figure (1)

5-Vaccine formulation:

Two formulae of vaccine were prepared:

\section{Formula (1): Montanide ${ }^{T M}$ ISA 71 VG formula:}

Water in oil emulsion vaccine was prepared using Montanide ${ }^{\mathrm{TM}}$ ISA $71 \mathrm{VG}$ at a ratio of $30 / 70(\mathrm{v} / \mathrm{v})$ aqueous/oil ratio. The aqueous medium is mixed into the MontanideTM ISA $71 \mathrm{VG}$ at room temperature with vigorous stirring (for 15-30 minutes), as instructed by the manufacturer. The antigen content in the prepared vaccines was adjusted to be not less than $10^{8.5}$ embryo infective dose $50 \%\left(\right.$ EID $\left._{50}\right)$.

\section{Formula (2): MSNPs formula:}

To adjust the same antigen content $\left(10^{8.5} /\right.$ dose $\left.\mathrm{EID}_{50}\right)$, nine parts of each inactivated virus fluid were mixed together with one part of (MSNPs) powder dissolved in Tris $\mathrm{HCl}$ 7.6-7.8 $\mathrm{pH}$ according to the method described by (Zongxi et al., 2012) and (Liu et al., 2019).

\section{6- Quality control of the prepared vaccines}

The prepared vaccines were tested for sterility, safety and purity tests following the standard international protocols as described by (CFR, 2019).

\section{7- Experimental Design:}

A total of 150 SPF chicks at 3 weeks old were used to evaluate the prepared vaccines and 40 SPF chicks at 3 weeks of age were used to evaluate the safety of both vaccines.

The chicks were divided into 3 groups, 50 chicks per each, group (1) Chicks vaccinated with Montanide $^{\mathrm{TM}}$ ISA 71 VG H9N2 vaccine, group (2) Chicks vaccinated with MSNPs H9N2 vaccine and group (3) unvaccinated control chicks kept without vaccination. All vaccinated chicks receive $0.5 \mathrm{ml}$ of prepared vaccines. Specific pathogen-free (SPF) chicks were obtained from SPF Egg Production Farm, Koum Osheim, El-Fayoum, Egypt and housed in brooder units within isolation facilities.

Blood samples were collected aseptically from the jugular vein of vaccinated and unvaccinated chicks weekly up to 12 weeks post-vaccination. The serum was separated and kept at $-20^{\circ} \mathrm{C}$ until to be used.

\section{8-Haemagglutination (HA) and Haem- agglutination inhibition (HI) tests:}

They were used to evaluate humoral immune response against LPAI A/chicken/Egypt/ $114922 \mathrm{v} / 2011$ (H9N2) and carried out on serum samples collected from vaccinated and unvaccinated chicken groups for 12 weeks after a single vaccination with the prepared vaccines. It is performed according to (OIE, 2019).

\section{9-Challenge test:}

Twenty-one days post-vaccination, twenty chicks from the vaccinated and unvaccinated groups were challenged with the LPAI A/chicken/Egypt/114922v/2011 (H9N2) kindly provided by National Laboratory for Veterinary Control on Poultry Production, Animal Health Research Institute (NLVCPP/AHI), Egypt. The birds were injected by Intra Muscular route $(0.5 \mathrm{ml})$ of allantoic fluid containing $10^{6} \mathrm{EID}_{50}$ of the challenged virus according to (OIE, 2019). Oropharyngeal swabs were collected at $2^{\text {nd }}, 4^{\text {th }}$ and $6^{\text {th }}$ days post-challenge (DPC) and tested by Real-Time PCR.

\section{0- Real-Time RT-PCR Assay:}

A- According to the manufacturer instructions, Extract avian Influenza virus RNA using QIAamp Viral RNA Mini kit (U SA).

B- According to the manufacturer's instructions

C- , the preparation of PCR Master Mix for H9 using QuantiTect probe RT-PCR kit (USA) was done

D- Using gene-specific probe and primer sets for influenza virus H9 (Ben Shabat et al., 2010)

\begin{tabular}{|c|c|l|}
\hline Gene & Name & Sequence \\
\hline H9 & $\mathrm{F}$ & GGAAGAATTAATTATTATTGGTCGGTAC \\
\hline & $\mathrm{R}$ & GCCACCTTTTTCAGTCTGACATT \\
\hline & Probe & [CY5]AACCAGGCCAGACATTGCGAGTAAGATCC[BHQ] \\
\hline
\end{tabular}

Transcription at $50^{\circ} \mathrm{C}$ for $30 \mathrm{~min}$ followed by initial denaturation at $95^{\circ} \mathrm{C}$ for $15 \mathrm{~min}, 40$ cycles of denaturation at $90^{\circ} \mathrm{C}$ for $15 \mathrm{sec}$ and annealing at 60 for $45 \mathrm{sec}$.

E- Using Applied Biosystems 7500 Fast Real-Time PCR System and software (USA).

The number of HA gene copies was quantified in a TaqMan ${ }^{\circledR}$ RT-PCR based on the positive control tenfold dilution of an in vitro transcribed RNA template of the challenged virus. A Ct value of 40 was selected as the cut-off between positive and negative results, and samples with $\mathrm{Ct}$ higher than 40 were considered negative for AIV. 


\section{1- Statistical analysis:}

The obtained results were analyzed statistically by an independent T-test using the SPSS program (SPSS, 2006).

\section{RESULTS $\backslash$}

\section{Scanning electron micrograph:}

As shown in Fig. (1), the electron micrograph illustrated the structure of the prepared MSNs by two different magnifications. It is clear at $(\mathrm{x} 40000)$ that the particles are of spherical shape with nearly equal diameters. Another striking feature is their homogenous distribution. Increasing magnification (x 100000) to get closer to the particle surface, it was observed that its size was about $50 \mathrm{~nm}$ and the porous nature of the particles has appeared hand in hand with marked roughness.
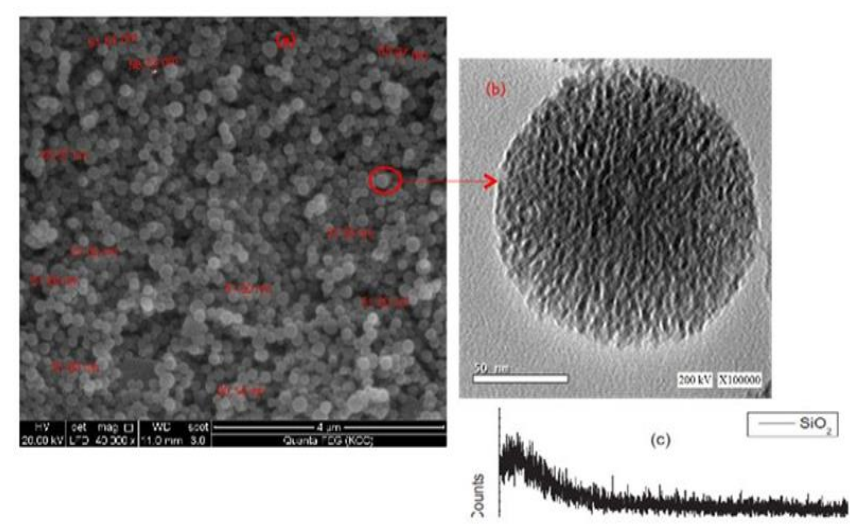

Fig. 1: Scanning electron micrographs of MSNs.

\section{2-Quality control of prepared vaccines: (OIE, 2019).}

Sterility test:

The prepared vaccines were found free from any bacterial, fungal and Mycoplasma contamination.

\section{Safety test:}

The vaccines were found to be safe and produced no clinical, local, and systemic or necropsy findings.

\section{3- HI test for chicken groups antibody assay:}

As shown in Table (1) and Fig. (2), it was noticed that group (2) exhibited a detectable and early high level of antibody titer against $\mathrm{H} 9 \mathrm{~N} 2$ virus at $2^{\text {nd }}$ and $3^{\text {rd }}$ weeks post-vaccination (wpv) as $\left(9.6 \log _{2}\right)$. On the other hand, the antibody titer against H9N2 in birds of the group (1) was slightly lower than those detected in the group (2) at the same weeks $\left(5.3 \log _{2}\right.$ and $8.6 \log _{2}$ ), respectively.
Table 1: The Mean AI-HI antibody titers in vaccinated chickens with prepared vaccines against $\mathrm{H} 9 \mathrm{~N} 2$ virus:

\begin{tabular}{|c|ccc|}
\hline \multirow{2}{*}{$\begin{array}{c}\text { Weeks } \\
\text { post- } \\
\text { vaccination }\end{array}$} & \multicolumn{3}{|c|}{$\begin{array}{c}\text { Mean AI-HI titer (log2) } \\
\text { in chicken groups }\end{array}$} \\
\cline { 2 - 4 } & Group 1* & Group 2* & Group 3 \\
\hline 1 & $4.6 \pm 1.39$ & $4.3 \pm 1.53$ & 0 \\
2 & $5.3 \pm 1.39$ & $9.6 \pm 1.53$ & 0 \\
3 & $8.6 \pm 1.39$ & $9.6 \pm 1.53$ & 0 \\
4 & $9.0 \pm 1.39$ & $7.6 \pm 1.53$ & 0 \\
5 & $8.3 \pm 1.39$ & $6.6 \pm 1.53$ & 0 \\
6 & $7.6 \pm 1.39$ & $7.6 \pm 1.53$ & 0 \\
7 & $8.6 \pm 1.39$ & $8.3 \pm 1.53$ & 0 \\
8 & $8.3 \pm 1.39$ & $9.3 \pm 1.53$ & 0 \\
9 & $8.0 \pm 1.39$ & $8.3 \pm 1.53$ & 0 \\
10 & $7.3 \pm 1.39$ & $7.6 \pm 1.53$ & 0 \\
12 & $7.6 \pm 1.39$ & $7.0 \pm 1.53$ & 0 \\
\hline
\end{tabular}

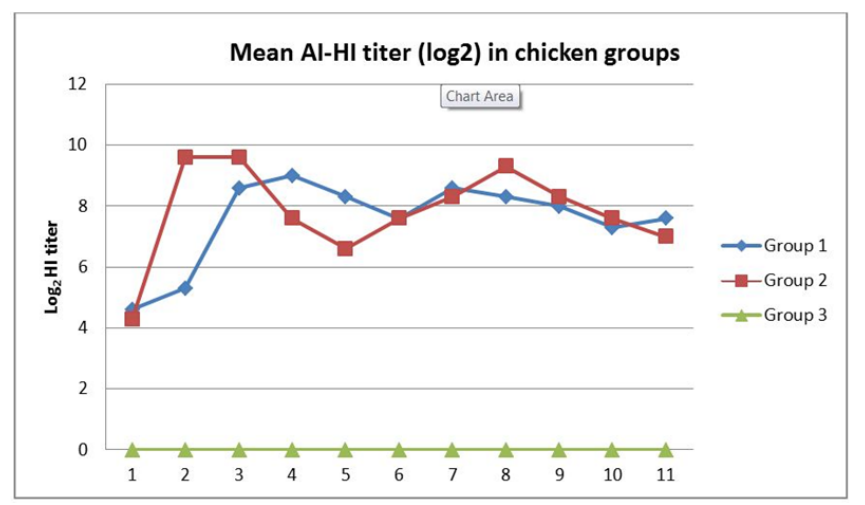

Fig. 2: The Mean AI-HI antibody titers in vaccinated chickens with prepared vaccines against $\mathrm{H} 9 \mathrm{~N} 2$ virus.

\section{4-Evaluation of virus shedding post challenge:}

By Real-Time RT-PCR, the shedding of the virus after challenge with H9N2 for groups (1) and (2) and unvaccinated control group (3) at interval days was measured. No shedding was detected in samples from the group (1) (received Montanide ${ }^{\mathrm{TM}}$ ISA $71 \mathrm{VG}$ formula vaccine) in $4^{\text {th }}$ and $6^{\text {th }}$ days post-challenge (DPC), whereas it showed very weak virus shedding at $2^{\text {nd }}$ DPC. Groups (2) (received MSNPs formula vaccine) showed a little amount of virus shedding starting from day 4 post-challenge by the $6^{\text {th }}$ DPC compared to the control group (3) that had the highest virus shedding value among all experimental groups (Table 2). Clinically, all groups showed no mortalities except some flu-like signs in the control unvaccinated group. 
Table 2: Results of real-time RT-PCR for detecting of H9N2 RNA copies of groups vaccinated with prepared vaccines post-challenge.

\begin{tabular}{|c|c|c|c|}
\hline $\begin{array}{l}\text { Time } \\
\text { point }\end{array}$ & Group & $\mathrm{Ct}^{*}$ & $\begin{array}{l}\text { Shedding } \\
\text { titer }\left(\mathrm{EID}_{50}\right)\end{array}$ \\
\hline \multirow{3}{*}{$2^{\text {nd }} \mathrm{DPC}^{* *}$} & 1 & 35.53 & $9.3 \times 10^{2}$ \\
\hline & 2 & $\mathrm{No} C t$ & No \\
\hline & 3 & 20.34 & $3.5 \times 10^{7}$ \\
\hline \multirow{3}{*}{$4^{\text {th }}$ DPC } & 1 & $\mathrm{No} C t$ & No \\
\hline & 2 & 24.24 & $\begin{array}{l}\text { shedding } \\
2.4 \times 10^{2}\end{array}$ \\
\hline & 3 & 21.9 & $1.2 \times 10^{7}$ \\
\hline \multirow{3}{*}{$6^{\text {th }}$ DPC } & 1 & $\mathrm{No} C t$ & No \\
\hline & 2 & 26.77 & $4.2 \times 10^{2}$ \\
\hline & 3 & 23.92 & $3.08 \times 10^{6}$ \\
\hline
\end{tabular}

$* \mathrm{Ct}=$ Cycle time (positive below 40).

$* * \mathrm{DPC}=$ days post challenge.

\section{DISCUSSION}

From its economic and epizootic importance, global and local vaccines against avian influenza were carried out and already have been produced. The use of MSNs is based on their unique intrinsic properties, including a large surface area, large pore size, excellent biocompatibility and biodegradability, and stable aqueous dispersion. MSNPs have received much attention in the last few decades because of their applications as a promising platform in the biomedicine field. The pore size of these porous structures ranges from 2 to $50 \mathrm{~nm}$, making them ideal candidates for various biomedical applications. (Jafari et al., 2018).

In this study, the Preparation of avian influenza H9N2 vaccine by utilizing Nano adjuvant (Mesoporous silica nanoparticles) was found efficient and provided the early and long duration of immunity in vaccinated chickens. As shown in Fig. (1), the scanning of MSNs by electron micrograph illustrated the structure of the prepared MSNs by two different magnifications. It is clear at $(x 40000)$ that the particles are of spherical shape with nearly equal diameters. Another striking feature is their homogenous distribution. Increasing magnification (x 100000) to get closer to the particle surface, it was observed that its size was about $50 \mathrm{~nm}$ and the porous nature of the particles was appeared hand in hand with marked roughness. These results agreed with (Liu et al., 2019).
Regarding quality control of the prepared vaccines, the results of sterility tests revealed that both vaccine candidates were sterile and free from any aerobic, anaerobic, fungal and Mycoplasma contaminations. These results are coming in parallel with the recommendation of (OIE, 2019).

The obtained safety test results revealed that all the inoculated chickens with both vaccine formulae survived all over the observation period and neither signs of local reactions as irritation nor systemic reactions that indicate both prepared vaccines were safe. These results agreed with (Bharti et al., 2015), who mentioned that mesoporous silica nanoparticles are used in controlling and targeting drug delivery systems due to their low toxicity and high drug loading capacity.

The experimental design was planned to evaluate the potency of the experimentally prepared vaccines formula 1 (avian influenza vaccine using Montanide $^{\mathrm{TM}}$ ISA $71 \mathrm{VG}$ adjuvant) and formula 2 (avian influenza vaccine using MSNPs) by measuring humoral immune response in vaccinated chicks. Evaluation of induced humoral immune response was carried out using Haemagglutination inhibition test (HI) as assessed by (Adrianus and Richard, 2009). They described the HI test as the benchmark for assessing the antigenic relationships between influenza viruses and post-infection serum.

It was noticed that the birds of the group (2) that received the H9N2 vaccine using MSNPs (formula 2) exhibited a detectable and early high level of antibody titer against the H9N2 virus at $2^{\text {nd }}$ and $3^{\text {rd }}$ weeks post-vaccination (wpv) as $\left(9.6 \log _{2}\right)$. On the other hand, the antibody titer against H9N2 in birds of the group (1) that received $\mathrm{H} 9 \mathrm{~N} 2$ vaccine using Montanide $^{\mathrm{TM}}$ ISA $71 \mathrm{VG}$ (formula 1) was slightly lower than those detected in the group (2) at the same weeks $\left(5.3 \log _{2}\right.$ and $8.6 \log _{2}$ ) respectively as shown in Table (1). Group (1) reached its maximum value at the 4th-week post-vaccination $\left(9.0 \quad \log _{2}\right)$. These results agreed with (Allan et al., 1978), who observed the appearance of the antibody against H9N2 in serum samples of vaccinated chicks from the first (wpv) till reached the peak of titer about 3-4 wpv after that began to decline slowly. While in the group (2), the maximum antibody value detected earlier at $2^{\text {nd }}, 3^{\text {rd }}$ weeks post-vaccination with non-significance increase. These results matched with studies of (Bharti et al., 2015) that focused on silica's unique mesoporous structure, which facilitates effective loading of drugs and their subsequent controlled release of the target site to improve the immune response. 
Viral shedding has a very significant parameter used to detect vaccine efficacy, and viral shedding control has the main role in limiting viral transmission (El-Masry et al., 2014). The chickens vaccinated with both H9N2 formulae was challenged using $10^{6} \mathrm{EID} 50 / \mathrm{ml}$ of challenged $\mathrm{H} 9 \mathrm{~N} 2$ virus at 21 days post-vaccination (6 weeks old), oropharyngeal swabs obtained at day 2,4 and 6 post-challenge for detection of the amount of viral shedding from the vaccinated group (1), (2) and non-vaccinated control group (3) (OIE, 2019). The results revealed that chickens of the group (1) vaccinated with formula 1 show a little amount of virus shedding as $9.3 \times 10^{2}$ at day 2 post-challenge, then the virus shed disappeared at $4^{\text {th }}$ and $6^{\text {th }}$ DPC. Group (2) vaccinated with formula 2 show very weak viral shedding starting from day 4 post-challenge till $6^{\text {th }} \mathrm{DPC}$ as $2.4 \times 10^{2}$ and $4.2 \times 10^{2}$ respectively but control non-vaccinated group (3), when challenged with the same dose of the challenged H9N2 strain, showed a high amount of virus shedding at day 2, 4 and 6 post-vaccination as showed in Table (2).

These results agreed with Bharti et al., (2015) and Trewyn et al., (2007), who explained the zigzag curve for serum antibodies produced by MSNPs vaccines and the rapid shot immune response in the first 2 weeks post-vaccination and also (Zongxi et al., 2012) who mentioned that silica nanoparticles (MSNs) have a large pore volume and surface area that act as efficient server carriers for many therapeutic agents. The functionalization of MSNPs with molecular, supramolecular or polymer moieties provides the material with great versatility such as performing vaccine adjuvant delivery tasks, which makes the delivery process highly controllable so the hollow MSNPs can achieve a super-high drug loading capacity due to the hollow cores which provide more space to load drugs, typically $>1 \mathrm{~g}$ drug/1 $\mathrm{g}$ of silica.

\section{CONCLUSION}

The obtained findings provide insight into a new formulation of inactivated avian influenza H9N2 vaccine using silica nanoparticles as innovated adjuvant to achieve a super-high drug loading efficient vaccine that provides early protection and long duration of immunity in vaccinated chickens.

\section{ACKNOWLEDGEMENTS}

We appreciate the financial support by Veterinary Serum and research institute (VSVRI), Abbasia, Cairo.

\section{AUTHORS CONTRIBUTION}

All authors contributed equally to study design, sampling, methodology, interpretation of results, and manuscript writing.

\section{Declaration of Conflicting Interests}

The authors revealed that there is no potential conflicts of interest.

\section{REFERENCES}

ABOUAITAH, K., A.A. FARGHALI, A. SWIDERSKASRODA, W. LOJKOWSKI, A.-F. RAZIN, and M. KHEDR, 2016. pH- Controlled release system for curcumin based on functionalized dendritic mesoporous silica nanoparticles, J. Nanomed. Nanotechnol, (7)351. DOI:10.4172/2157-7439.1000351.

ADRIANUS, C.M., and RICHARD, J.W., 2009. "Antigenic cross-reactivity among H5N1 viruses" Chapter-2. Cited in vaccines for pandemic influenza. Book. Edited by Richard W. Compans and Walter A. Orenstein.

ALI, M., YAQUB, T., MUKHTAR, N., IMRAN, M., GHAFOOR, A., SHAHID, M.F., YAQUB, S., SMITH, G.J.D., SU, Y.C.F., and NAEEM, M., 2018. Prevalence and phylogenetics of $\mathrm{H} 9 \mathrm{~N} 2$ in backyard and commercial poultry in Pakistan. Avian Diseases, 62(4): 416-424.

ALLAN, W.H., LANCASTER, J.E., and TOTH, B., 1978. Newcastle disease vaccines their production and use. FAO Animal Production and Health Series No. 10. FAO: Rome, Italy.

BEN SHABAT, M., MEIR, R., HADDAS, R., LAPIN, E., SHKODA, I., RAIBSTEIN, I., PERK, S., and DAVIDSON, I., 2010. Development of a real-time TaqMan RT-PCR assay for the detection of H9N2 avian influenza viruses. J Virol Methods.168 (12):72-7. DOI: $10.1016 /$ j.jviromet.2010.04.019. Epub 2010 May 6.

BHARTI, C., NAGAICH, U., PAL, A.K., and GULATI, N., 2015. Mesoporous silica nanoparticles in target drug delivery system: A review. Int J Pharm Investig. 5(3):124-133. DOI:10.4103/2230-973X.160844.

CODE OF AMERICAN FEDERAL REGULATION CFR., 2019. Office of the Federal Register National Archives Records Service. Animals and Animal products. Ch. 111. Office of the federal register National Archives Records Administration, USA.

DELANY, I., RAPPUOLI, R., and DE, G.E., 2014. Vaccines for the 21st Century. EMBO Mol Med 6:708-720. DOI: $10.1002 / \mathrm{emmm} .201403876$.

EL-MASRY, I., RIJIKS, J., PEYRE, M., TYLOR,N., LUBROTH, J., JOBER, Y., 2014. Modeling influenza A $\mathrm{H} 5 \mathrm{~N} 1$ vaccination strategy scenarios in the house hold poultry setaries in Egypt. Topical animal health and production. 46 (1): 57-63.

EL-ZOGHBY, EF, ARAFA, AS, HASSAN, MK, ALY, MM, SELIM, A., KILANY, W.H., SELIM, U., NASEF, S., AGGOR, M.G., ABDELWHAB, E.M., and HAFEZ, H.M., 2012. Isolation of H9N2 avian influenza virus from bobwhite quail (Colinus virginianus) in Egypt. Arch. Virol., 157(6): 11671172. DOI: 10.1007/s00705-012-1269-z. Epub 2012 Mar 17.

JAFARI S, DERAKHSHANKHAH H, ALAEI L, FATTAHI, A,, VARNAMKHASTI, B.S., and SABOURY, A.A., 2018. Mesoporous silica nanoparticles for therapeutic/diagnostic applications. 
Biomed Pharmacother.109:1100-1111. DOI: 10.1016/j.biopha. 10.167. Epub. PMID: 30551360.

KRESGE, C.T., LEONOWICZ, M.E., and ROTH, WJ., 1992., Ordered mesoporous molecular sieves synthesized by a liquid-crystal template mechanism. Nature. 359:710-2.

DOI https://DOI.org/10.1038/359710a0.

LIU, Z., RU, J., SUN, S., TENG, Z., DONG, H., SONG, P., and GUO, H., 2019. Uniform dendrimer-like mesoporous silica nanoparticles as a nano-adjuvant for foot-and-mouth disease virus-like particle vaccine. Journal of Materials Chemistry B, 7(21), 3446-3454. DOI:10.1039/C8TB03315C.

MERCURI, LP., CARVALHO, L.V., LIMA, F.A., QUAYLE, C., and FANTINI, M.C., 2006. Ordered mesoporous silica SBA-15: a new effective adjuvant to induce antibody response. Small 2:254-256. DOI: $10.1002 / \mathrm{smll} .200500274$.

NAGUIB, M.M., VERHAGEN, J.H., SAMY, A., ERIKSSON, P., FIFE, M., LUNDKVIST, A, ELLSTRÖM, P., and JÄRHULT, J.D., 2019. Avian influenza viruses at the wild-domestic bird interface in Egypt. Infect. Ecol. Epidemiol., 9(1): 1575687. d o i: 10.1080/20008686.2019.1575687

OIE TERRESTRIAL., 2019. Chapter 3.3.4.

SOOYEON K, SINGH, R.K., and WOJCIECH, C., 2013. Silica-based mesoporous nanoparticles for controlled drug delivery. J Tissue Eng. 4:1-35. DOI: 10.1177/2041731413503357.

SWAMI A, JINJUN S, SURESH G, VOTRUBA RA, NAGESH K., and FAROKHZAD CO., 2012. Nanoparticles for targeted and temporally controlled drug delivery. In book: Multifunctional Nanoparticles for Drug Delivery Applications. pp. 9-25. DOI:10.1007/978-1-4614-2305-8_2.

SPSS. 2006. SPSS for windows releases 14.0.0,12 June 2006. standard version, copyright SPSS Inc.19892006 All right reserved, copy right ${ }^{\circledR S P S S}$.

SWAYNE, DE; SPAKMAN, E., and PANTINJACWOOD, M., 2014. Success factor for avian influenza vaccine use in poultry and potential impact at wild bird-agricultural interface. Ecohealth. 11 (1): 94-108.

SYAMSIAH AINI S., LEOW B.L.,FAIZUL FIKRI M.Y., MUHAMMAD REDZWAN S., ONG G.H., and FAIZAH HANIM M.S., 2019. Genetic analysis of h9n2 avian influenza viruses isolated from chickens in Malaysia from 2015- 2018. Malaysian Journal of Veterinary Research. Volume 10 no. 2. 7992

TREWYN BG, SLOWING II, GIRI S, CHEN H.T., and LIN VS., 2007. Synthesis and functionalization of a mesoporous silica nanoparticle-based on the sol-gel process and applications in controlled release. Acc Chem Res. 40:846-53. DOI.org/10.1021/ar600032u.

ZONGXI LI, JONATHAN C. BARNES, ALEKSANDR BOSOY, J. FRASER STODDART and JEFFREY I. ZINK, 2012. Mesoporous silica nanoparticles in biomedical applications. Chem. Soc. Rev., 41, 2590-2605. DOI: 10.1039/c1cs15246g.

\section{How to cite this article:}

Amani Mohamed Abbas, Abd El-Moneam M. M., H.M. El Naggar, S.I. El-Dek, Ahmed Ali, and Mohamed Fekry El Kersh, 2022. Trials of Using a Novel Nanoparticle as An Adjuvant for Inactivated Aavian Influenza Vaccine. Journal of Applied Veterinary Sciences, 7 (1): 31- 37.

DOI:https://dx.doi.org/10.21608/javs.2021.100437.1110 